ISSN : $1225-9918$

\title{
Thiobarbituric Acid Reactive Substances Levels in Brain Tissue of Aldh2 Knockout Mice Following Ethanol Exposure for 8 Weeks
}

Sun-In Moon', Sang-Yong Eom', Jung-Hyun Kim', Dong-Hyuk Yim', Hyong-Kyu Kim², Yong-Dae $\mathrm{Kim}^{1}{ }^{*}$ and Heon $\mathrm{Kim}^{1}$

${ }^{1}$ Department of Preventive Medicine, College of Medicine and Medical Research Institute, Chungbuk National University, Cheongju 361-763, Korea

${ }^{2}$ Department of Microbiology, College of Medicine and Medical Research Institute, Chungbuk National University, Cheongju 361-763, Korea

Received May 17, 2011 /Revised June 11, 2011 / Accepted June 20, 2011

\begin{abstract}
Excessive alcohol consumption causes various degenerative brain diseases including Alzheimer's disease and Parkinson's disease. Absorbed ethanol is metabolized to acetaldehyde and acetic acid by alcohol dehydrogenase (ADH) and aldehyde dehydrogenase (ALDH). Acetaldehyde is well known as a toxicant through generation of reactive oxygen species (ROS). Therefore, ALDH2 activity may play important roles in the pathogenesis of alcohol-induced brain diseases. In this study, we demonstrated the effects of ALDH2 enzyme activity on lipid peroxidation in brain tissues and urine of mice exposed to ethanol for 8 weeks. Five male, 8-week old Aldh2 (+/+) and Aldh2 (-/-) mice (C57BL/6J strain) in each group were exposed to ethanol for 8 weeks $(2 \mathrm{~g} / \mathrm{kg}$ wt./day) using gavage, and those in the control group received $0.9 \%$ saline alone. Thiobarbituric acid reactive substances (TBARS) level, a marker for lipid peroxidation, was measured in whole brain tissue and urine by high performance liquid chromatography. As a result, chronic ethanol treatment did not show any statistical change on the TBARS level of brain tissue in both $A l d h 2(+/+)$ mice and in Aldh2 (-/-) mice. However, following ethanol exposure for 8 weeks in $A l d h 2(-/-)$ mice, the urinary TBARS levels were significantly increased to more than double compared to the pretreatment group. This result was not observed in Aldh2 $(+/+)$ mice. These results suggest that although ALDH2 enzyme activity plays a role in the generation of ROS in the whole body, it does not seem to be important in the pathogenesis of alcohol induced degenerative brain diseases.
\end{abstract}

Key words : Aldehyde dehydrogenase 2, thiobarbituric acid reactive substances, brain, knockout mice

\section{서 론}

과다한 음주는 각종 만성 퇴행성 뇌질환의 대표적인 원인 중 하나로 알려져 있다[2,7]. 특히, 알츠하이머 질환 (Alzheimer's disease)은 인지능력과 행동능력 두 가지에 모두 영향을 미치는 진행적 노인성 치매증의 하나로 알코올의 과량 섭취 및 반복적인 섭취가 알코올성 기억상실(Alcohol-induced blackouts)을 유발하는 등 알츠하이머 질환의 중요한 인자로 알려져 있다. 알츠하이머 질환의 발생 기전에 대한 다 양한 가설이 제기되고 있으나 그 중 가장 설득력 있게 받아들 여지는 가설 중 하나가 활성산소(Reactive oxygen species, $\mathrm{ROS})$ 에 의한 산화적스트레스 관련설이다.

체내에 유입된 에탄올은 알코올 탈수소효소(alcohol dehydrogenase, $\mathrm{ADH}$ )에 의해 아세트알데히드로 대사된 후 다시 알데히드탈수소효소 2(aldehyde dehydrogenase 2, $\mathrm{ALDH} 2$ )에 의해 아세트산으로 대사되어 배출된다[1]. 에탄올

*Corresponding author Tel : +82-43-261-2845, Fax : +82-43-274-2965

E-mail : ydkim@chungbuk.ac.kr
의 대사과정 중에는 다량의 free radical이 생성되어 체내에서 산화적 스트레스를 유발하는 것으로 알려져 있고[3,7,15], 알코 올의 단기간 투여가 활성산소의 생성을 증가시킨다는 보고도 있다[2,19]. 한국인을 포함한 아시아 인종의 약 $50 \%$ 는 $A L D H 2$ gene의 점돌연변이로 인해 ALDH2 활성이 저하된 유전자형 을 지니고 있고[10,18], $\mathrm{ALDH} 2$ 활성이 저하된 경우는 그렇지 않은 경우에 비해 몇몇 질병의 발생률이 유의하게 높은 것으 로 알려져 있다[23]. 최근, Ohta 등[17]이 일본인을 대상으로 한 역학연구에 따르면 $\mathrm{ALDH} 2$ 효소의 활성이 알츠하이머 질 환의 발생에서 매우 중요한 역할을 한다고 보고하고 이 기전 에 산화적스트레스가 관여하고 있음을 제시하였다. 그러나 한 국인을 대상으로 한 Shin 등[19]의 연구에서는 ALDH2 효소의 유전자다형성이 알츠하이머 발생과 관련이 없다고 보고하여 $\mathrm{ALDH} 2$ 유전자 다형성과 알츠하이머 질환과의 관련성은 아 직 명확치 않다. 사람을 대상으로 한 역학연구에서 질환과 관 련된 다양한 인자들을 모두 통제하기는 어렵기 때문에 $\mathrm{ALDH} 2$ 효소가 결핍된 동물 모델을 이용하여 확인하는 것이 논란 해결의 중요한 단서를 제공할 수 있을 것으로 생각된다. 본 연구진은 선행연구를 통하여 고농도의 단기간 에탄올 
투여에 의한 산화적 유전자 손상정도가 ALDH2 효소의 활성 이 결핍된 경우에 더욱 심각하다는 연구 결과를 보고한 바 있다[11,12]. 그러나 알츠하이머와 같은 만성 뇌질환을 평가하 기 위해서는 에탄올에 대한 만성노출 평가가 필수적이다. 본 연구에서는 ALDH2 효소가 결핍된 knockout mice에 8주간 에탄올을 경구 투여한 후 뇌조직과 소변에 존재하는 thiobarbituric acid reactive substances (TBARS)의 농도변화 를 평가하고 이러한 변화가 ALDH2 효소의 활성에 따라 어떻 게 달라지는지 비교하였다.

\section{재료 및 방법}

\section{실험 동물}

Aldh2 (-/-) 마우스[13]를 일본의 Kawamoto 교수로부터 분양받아 실험에 사용하였다. 12 주령의 수컷 $A l d h 2(+/+)$ 및 Aldh2 (-/-) (C57BL/6J strains)를 plastic mouse cages에서 12시간(07:00 19:00)은 밝게, 나머지 12시간(19:00 07:00)은 어두운 상태로 유지시켰으며 배양실의 온도는 $23 \sim 25^{\circ} \mathrm{C}$ 를 유 지하였다. 동물실험과 관련된 모든 조작은 미국 보건원이 발 간한 '실험동물의 사용과 관리에 관한 규정'[14]에 따라 시행하 였다.

\section{Aldh2 genotyping 및 ethanol 투여}

마우스 꼬리부분에서 genomic DNA를 추출하여 PCRamplification 방법으로 Aldh2 genotype을 결정하였다[9]. 각 군에 5 마리씩의 마우스를 배정하여 알코올 투여군에는 $20 \%$ ethanol $(2 \mathrm{~g} / \mathrm{kg} /$ day) 을 8주간 매일 1회 경구 투여하였다.

Thiobarbituric acid reactive substances (TBARS)
농도 측정

TBARS 농도는 Ohkawa 등[16]의 방법을 다소 수정하여 사 용하였다. 마우스로부터 분리한 뇌조직 $0.1 \mathrm{~g}$ 정도를 $20 \mathrm{mM}$ Tris- $\mathrm{HCl}$ buffer (pH 7.4) $1 \mathrm{ml}$ 에 넣어 초음파로 분쇄하고 $3,000 \times \mathrm{g}, 4^{\circ} \mathrm{C}$ 에서 15 분간 원심분리 한 다음 상층액 $50 \mu \mathrm{l}$ 를 취하여 $0.05 \%$ BHT $50 \mu \mathrm{l}, 0.1 \mathrm{~N} \mathrm{HNO}_{3} 150 \mu \mathrm{ll}, 42 \mathrm{mM} \mathrm{TBA}$ $150 \mu 1$ 를 넣고 30 초간 잘 섞어주었다. $100^{\circ} \mathrm{C}$ 에서 1 시간 동안 방치한 후 5 분간 ice에 방치하였다. n-Butanol $300 \mu 1$ 를 넣고 30 초간 잘 섞어준 후 $12,000 \times g$ 에서 5 분간 원심분리하고 상층 액 $250 \mu 1$ 를 고압액체크로마토그래피(HPLC) 방법으로 분석 하였다. 한편, 마우스에서 채취한 24시간 소변 $50 \mu 1$ 를 취하여 0.05\% BHT $50 \mu \mathrm{ll}, 0.1 \mathrm{~N} \mathrm{HNO}_{3} 150 \mu \mathrm{l}, 42 \mathrm{mM} \mathrm{TBA} 150 \mu \mathrm{l}$ 를 넣고 30 초간 잘 섞어준 다음 조직에서와 동일한 방법으로 분 석하였다. HPLC는 Model SP930D 펌프(Young Lin, Anyang, Korea)와 Model SIL-10ADvp 자동시료주입기(Shimadzu, Kyoto, Japan), 그리고 Model SPD-10Avp 자외선 검출기 (Shimadzu), Autochro-3000 Data system (Young Lin) 등으로
구성된 것을 사용하였다. 컬럼은 Tosoh사(Tokyo, Japan)의 TSK gel ODS-80, $4.4 \times 15 \mathrm{~mm}$ 역상 컬럼을 이용하였다. 이동상 용액으로는 $50 \mathrm{mM}$ potassium monobasic phosphate: acetonitrile : methanol (65:15:20, pH 6.8) 용액을 사용하였으 며, 분당 $1 \mathrm{ml}$ 의 속도로 흘려주었다. 자외선 검출기 파장은 $532 \mathrm{~nm}$ 를 사용하였다.

\section{통계분석}

통계분석은 윈도우용 SPSS (Version 12.0)를 사용하였다. 군 간의 TBARS 농도는 Wilcoxon signed rank test와 반복측정분 산분석(repeated measures ANOVA)을 이용하여 분석하였으 며 $\mathrm{p}$-값이 0.05 이하인 경우를 유의한 것으로 판정하였다.

\section{결과 및 고찰}

$\mathrm{ALDH} 2$ 효소는 미토콘드리아의 매트릭스에 존재하며 에탄 올이 대사되어 만들어진 아세트알데히드를 아세트산으로 분 해시키는 역할을 한다. ALDH2 유전자의 12번 exon의 점돌연 변이에 의해 유발되는 $A L D H 2$ (비활성)형은 우리나라, 일본, 중국 등의 북동 아시안에만 국한되어 나타나는 것으로 알려져 있으며 이 유전자형을 가진 사람에서 음주 후에 얼굴 홍조, 두통 등이 나타나는 alcohol flushing syndrome은 체내의 상 승된 아세트알데히드가 그 원인인 것으로 알려져 있다. 또한, $\mathrm{ALDH} 2$ 유전자다형성은 음주에 의한 암발생과도 관련이 있 는 것으로 알려져 있다[21-23]. $A L D H 2$ 유전자형을 가진 사 람은 $A L D H 2^{\star 1}$ (활성형)을 가진 사람에 비해 식도암의 위험도 가 7 12배 가량 높은 것으로 보고되었다. Yokoyama 등[23]의 연구에서도 적어도 하나의 $A L D H 2$ 유전자를 가진 사람은 혈중 아세트알데히드 농도가 상대적으로 높으며, 이것이 알코 올과 관련된 식도암에서 중요한 원인으로 작용할 가능성이 매우 크다고 보고한 바 있다.

다양한 유전적, 환경적 요인이 복합적으로 관여하는 만성 뇌신경질환의 발생에서 알코올 섭취는 중요한 위험요인 중 하나로 알려져 있다. 이는 에탄올과 대사산물인 아세트알데히 드가 뇌조직의 신경전달체계인 muscarinic cholinergic receptor 또는 serotonin에 영향을 주기 때문인 것으로 알려져 있다. Zhang 등[24]은 최근 배양 세포(myocyte)에 아세트알데 히드를 노출시키면 활성산소의 생성이 증가된다고 보고하였 으며 Isse 등[8]의 연구에서도 Aldh2 knockout 마우스는 wildtype 마우스에 비해 혈중 알데히드 농도가 유의하게 높다 고 보고하였다. 이러한 연구결과들은 에탄올 대사산물인 아세 트알데히드에 의해 발생하는 활성산소가 뇌신경질환 발생에 서 매우 중요한 역할을 할 가능성을 시사하며 결과적으로 $\mathrm{ALDH} 2$ 효소의 활성에 따라 알코올성 뇌신경질환의 발생 양 상이 달라질 수 있음을 의미한다.

Malondialdehyde (MDA)는 지질과산화에 대한 지표로서 
8-OHdG와 더불어 대표적인 산화적스트레스 지표로 이용된 다[6]. 포화지방산에서 생성되는 과산화지질은 매우 불안정하 여 복잡한 형태의 다른 화합물로 대사되는데, 여기에는 $\mathrm{MDA}$ 등의 카보닐화합물이 포함되며, 이와 같은 과산화지질의 증가 는 다양한 종류의 만성질환 발생과 관련이 있는 것으로 알려 져 있다[4,5]. 본 연구에서는 8 주간 에탄올을 경구 투여한 마우 스의 소변과 뇌조직에서 TBARS 농도를 측정하고 이를 $\mathrm{ALDH} 2$ 효소의 활성에 따라 비교함으로써 에탄올에 의한 만 성 뇌신경질환의 발생에서 $\mathrm{ALDH} 2$ 효소의 역할을 평가해 보 고자 하였다. 그 결과, 뇌조직에서의 TBARS 농도는 Aldh2 $(+/+)$ 마우스의 경우 대조군이 4.22 , 에탄올 투여군이 4.36 $\mu \mathrm{mol} / \mathrm{\mu g}$ protein 농도를 보인 반면, Aldh2 (-/-) 마우스의 경우는 대조군이 3.53, 에탄올 투여군이 $3.09 \mu \mathrm{mol} / \mu \mathrm{g}$ protein 농도를 보여 양군 모두 8 주간의 에탄올 투여에 의해 통계적으 로 유의한 농도변화를 나타내지 않았다(Fig. 1). 이와 같은 결 과는 본 연구진의 처음 예상과는 달리 만성 에탄올 섭취에 의한 뇌조직의 산화적스트레스 발생에서 ALDH2 효소의 역 할이 그다지 중요하지 않을 가능성을 시사한다. 알코올 섭취 로 인해 발생할 수 있는 대표적인 만성 뇌신경질환인 알츠하 이머 질환과 ALDH2 효소의 유전자다형성과의 관련성에 대 해서는 아직 많은 논란이 있다. Ohta 등[17]이 일본인을 대상 으로 한 역학연구에 따르면 ALDH2 효소의 활성이 알츠하이 머 질환의 발생에서 매우 중요한 역할을 한다고 보고하고 이 기전에 산화적스트레스가 관여하고 있음을 제시한 반면, 한국 인을 대상으로 한 Shin 등[20]의 연구에서는 ALDH2 효소의 유전자다형성이 알츠하이머 발생과 관련이 없다고 보고하였 고 몽골인을 대상으로 한 최근의 다른 역학 연구에서도 동일 한 결과를 보고하여 ALDH2 유전자 다형성과 알츠하이머 질 환과의 관련성은 아직 명확치 않다. 역학연구가 질환과 관련 된 다양한 인자들을 완벽하게 통제하기 어려운 단점이 있음을 감안하면, 본 연구의 결과는 ALDH2 효소 활성 이외의 모든 인자들을 완벽히 통제할 수 있으므로 논란 해결의 중요한 실 마리를 제시할 수 있다. 본 연구의 결과는 ALDH2 효소의 활 성이 에탄올 투여에 의한 뇌조직에서의 활성산소 생성에서

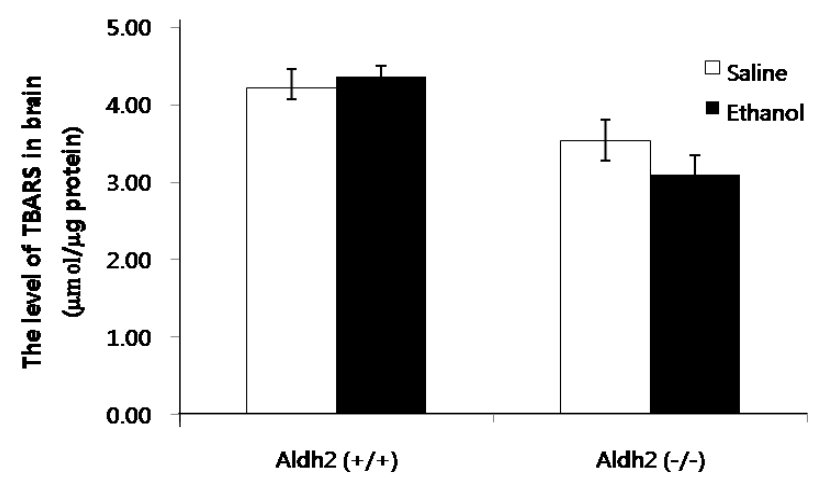

Fig. 1. The level of TBARS in brain of mice treated with saline or ethanol for 8 weeks.

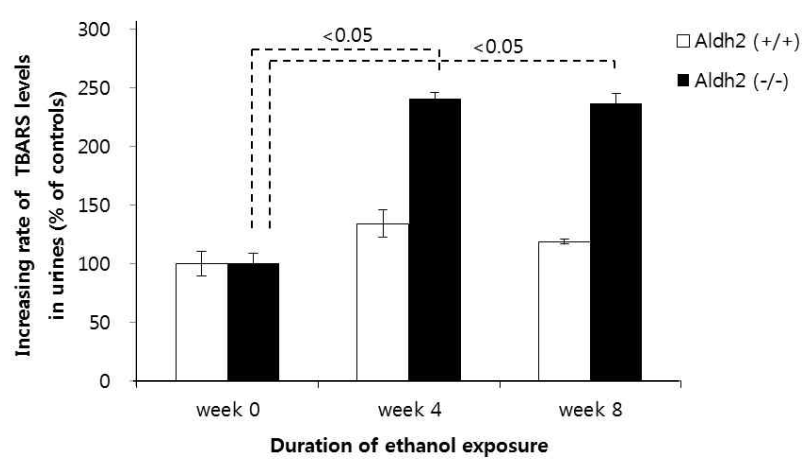

Fig. 2. The level of TBARS in urine of mice treated with saline or ethanol for 8 weeks. Statistical analysis was performed by Wilcoxon signed rank test or repeated measures ANOVA. $p<0.05$ compared with each group.

중요하게 작용하지 않음을 시사하지만, 이 결과로부터 특정 뇌질환과 ALDH2 효소 활성과의 관련성을 직접 평가하는 것 은 무리가 있다. 왜냐하면, 본 연구에서는 에탄올 투여에 의한 특정 질환의 발생 여부를 확인하지 않았기 때문이다.

한편, 에탄올 투여 전 대비 투여 4 주 후, 8 주 후의 요중 TBARS 농도를 비교한 결과, Aldh2 (+/+) 마우스의 경우가 각 각 $134.1 \%$ 와 $118.8 \%$ 를 보인 반면, Aldh2 (-/-) 마우스는 $241.1 \%$ 와 236.4\%를 나타내 투여 전에 비해 2배 이상 유의하게 증가한 것으로 나타났다(Fig. 2). 요중 TBARS 농도는 특정 장 기가 아닌 전신에서 생성되는 산화적스트레스를 반영하는 것 이므로 본 연구결과는 $\mathrm{ALDH} 2$ 효소가 뇌 조직에서의 활성산 소 생성과는 관련성이 없지만 뇌가 아닌 다른 장기에서의 산 화적스트레스 발생과는 관련성이 있을 가능성을 시사해준다. 특히, 에탄올 대사가 활발하게 이루어지는 간조직과 관련되어 있을 가능성이 가장 크다. 본 연구진이 기존에 수행한 연구[12] 에서도 Aldh2 (-/-) 마우스의 간조직 내 $\mathrm{MDA}$ 농도는 Aldh2 $(+/+)$ 마우스에 비해 통계적으로 유의하게 높게 나타나 이와 같은 주장을 뒷받침해준다.

요약하면, 본 연구의 결과는 8 주간 에탄올을 경구 투여한 마우스에서 ALDH2의 활성은 체내에서의 전반적인 활성산소 생성에는 중요하게 관여하는 것으로 보이지만 뇌조직에서의 활성산소 생성에는 영향을 주지 않는 것으로 나타났다. 이는 에탄올 노출과 이에 따른 활성산소의 생성이 다양한 만성 뇌 질환을 유발한다는 기존의 가설에서 $\mathrm{ALDH} 2$ 의 활성이 중요 하게 관여하지 않을 가능성을 시사한다.

\section{감사의 글}

이 논문은 2007년 정부(교육과학기술부)의 재원으로 한국 연구재단의 지원을 받아 수행된 연구이며(KRF-2007-313$\mathrm{E} 00181)$, 이에 감사드립니다. 


\section{References}

1. Agarwal, D. P. and H. W. Goedde. 1992. Pharmacogenetics of alcohol metabolism and alcoholism. Pharmacogenetics 2, 48-62.

2. Bondy, S. C. and J. Orozco. 1994. Effects of ethanol treatment upon sources of reactive oxygen species in brain and liver. Alcohol and Alcoholism 29, 375-383.

3. Bondy, S. C. 1992. Ethanol toxicity and oxidative stress. Toxicol. Lett. 63, 231-241.

4. Browne, S. E. and M. F. Beal. 2006. Oxidative damage in Huntington's disease pathogenesis. Antioxid Redox. Signal 8, 2061-2073.

5. De Maria, N., A. Colantoni, S. Fagiuoli, G. J. Liu, B. K. Rogers, F. Farinati, D. H. Van Thiel, and R. A. Floyd. 1996. Association between reactive oxygen species and disease activity in chronic hepatitis C. Free Radic. Biol. Med 21, 291-295.

6. Esterbauer, H., R. J. Schaur, and H. Zollner. 1991. Chemistry and biochemistry of 4-hydroxynonenal, malonaldehyde and related aldehydes. Free Radic. Biol. Med 11, 81-128.

7. Ishii, H., I. Kurose, and S. Kato. 1997. Pathogenesis of alcoholic liver disease with particular emphasis on oxidative stress. J. Gastroenterol. Hepatol. 12, 272S-282S.

8. Isse, T., K. Matsuno, T. Oyama, K. Kitagawa, and T. Kawamoto. 2005. Aldehyde dehydrogenase 2 gene targeting mouse lacking enzyme activity shows high acetaldehyde level in blood, brain, and liver after ethanol gavages. Alcohol. Clin. Exp. Res. 29, 1959-1964.

9. Isse, T., T. Oyama, T. Kitagawa, K. Matsuno, A. Matsumoto, and A. Yoshida. 2002. Diminished alcohol preference in transgenic mice lacking aldehyde dehydrogenase activity. Pharmacogenetics 12, 621-626.

10. Kee, J. Y., M. O. Kim, I. Y. You, J. Y, Chai, E. S. Hong, and S. C. An. 2003. Effects of genetic polymorphisms of ethanol-metabolizing enzymes on alcohol drinking behaviors. Taehan Kan Hakhoe Chi 9, 89-97.

11. Kim, Y. D., T. Oyama, T. Isse, H. Kim, and T. Kawamoto. 2005. Expression levels of hepatic cytochrome P450 enzymes in Aldh2-deficient mice following ethanol exposure: a pilot study. Arch Toxicol. 79, 192-195.

12. Kim, Y. D., S. Y. Eom, M. Ogawa, T. Oyama, T. Isse, J. W. Kang, Y. W. Zhang, T. Kawamoto, and H. Kim. 2007. Ethanol-induced oxidative DNA damage and CYP2E1 expression in liver tissue of Aldh2 knockout mice. J. Occup. Health 49, 363-369.

13. Kitagawa, K., T. Kawamoto, N. Kunugita, T. Tsukiyama, K. Okamoto, and A. Yoshida. 2000. Aldehyde dehydrogenase (ALDH) 2 associates with oxidation of methoxyacetaldehyde; in vitro analysis with liver subcellular fraction derived from human and Aldh2 gene targeting mouse. FEBS Lett. 476, 306-311.

14. National Research Council (US) Committee. 2011. Guide for the Care and Use of Laboratory Animals. 8th edition. National Academies Press (US). Washington D.C.

15. Nordmann, R., C. Ribiere, and H. Rouach. 1992. Implication of free radical mechanisms in ethanol-induced cellular injury. Free Radic. Biol. Med 12, 219-240.

16. Ohkawa, H., N. Ohishi, and K. Yagi. 1979. Assay for lipid peroxides in animal tissues by thiobarbituric acid reaction. Anal. Biochem 95, 351-358.

17. Ohta, S., I. Ohsawa, K. Kamino, F. Ando, and H. Shimokata. 2004. Mitochondrial ALDH2 deficiency as an oxidative stress. Ann. N. Y. Acad Sci. 1011, 36-44.

18. Oyama, T., T. Isse, N. Kagawa, T. Kinaga, Y. D. Kim, and M. Morita. 2005. Tissue-distribution of aldehyde dehydrogenase 2 and effects of the ALDH2 gene-disruption on the expression of enzymes involved in alcohol metabolism. Front. Biosci. 10, 951-960.

19. Reinke, L. A., Y. Kotake, P. B. McCay, and E. G. Janzen. 1991. Spin-trapping studies of hepatic free radicals formed following the acute administration of ethanol to rats: in vivo detection of 1-hydroxyethyl radicals with PBN. Free Radic. Biol. Med 11, 31-39.

20. Shin, I. S., R. Stewart, T. M. Kim, S. W. Kim, S. T. Yang, H. Y. Shin, J. S. Jung, and J. S. Yoon. 2005. Mitochondrial aldehyde dehydrogenase polymorphism is not associated with incidence of Alzheimer's disease. Int. J. Geriatr. Psychiatry 20, 1075-1080.

21. Yokoyama, A., T. Muramatsu, T. Ohmori, T. Yokoyama, K. Okuyama, H. Takahashi, Y. Hasegawa, S. Higuchi, K. Maruyama, K. Shirakura, and H. Ishii. 1998. Alcohol-related cancers and aldehyde dehydrogenase-2 in Japanese alcoholics. Carcinogenesis 19, 1383-1387.

22. Yokoyama, A., T. Muramatsu, T. Omori, T. Yokoyama, S. Matsushita, S. Higuchi, K. Maruyama, and H. Ishii. 2001. Alcohol and aldehyde dehydrogenase gene polymorphisms and oropharyngolaryngeal, esophageal and stomach cancers in Japanese alcoholics. Carcinogenesis 22, 433-439.

23. Yokoyama, A., H. Watanabe, H. Fukuda, T. Haneda, H. Kato, and T. Yokoyama. 2002. Multiple cancers associated with esophageal and oropharyngolaryngeal squamous cell carcinoma and the aldehyde dehydrogenase- 2 genotype in male Japanese drinkers. Cancer Epidemiol. Biomarkers Prev. 11, 895-900.

24. Zhang, X. S., Y. Li, R. A. Brown, and J. Ren. 2004. Ethanol and acetaldehyde in alcoholic cardiomyopathy: from bad to ugly en route to oxidative stress. Alcohol 32, 175-186. 
초록 : Aldh2 knockout 마우스에서 8주간 에탄올 노출에 따른 뇌조직의 thiobarbituric acid reactive substances 농도

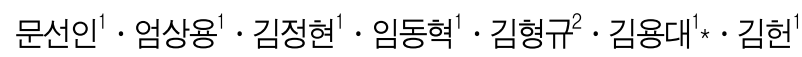

(충북대학교 의과대학 예방의학교실, ${ }^{2}$ 충북대학교 미생물학교실 및 의학연구소)

과다한 음주는 알츠하이머 및 파킨슨 질병과 같은 각종 만성 퇴행성 뇌질환의 대표적인 원인 중 하나로 알려져 있다. 체내에 유입된 에탄올은 알코올 탈수소효소(alcohol dehydrogenase, ADH)에 의해 아세트알데히드로 대사 된 후 다시 알데히드탈수소효소 2(aldehyde dehydrogenase 2, ALDH2)에 의해 아세트산으로 대사되어 배출된다. 에탄올의 대사과정 중에는 다량의 free radical이 생성되어 체내에서 산화적 스트레스를 유발하는 것으로 알려져 있고, 아세트알데히드는 활성산소를 생산하는 독성물질로 잘 알려져 있다. 본 연구에서는 8 주간 에탄올에 노출된 Aldh2 knockout 마우스를 사용하여 ALDH2 효소 활성이 뇌 조직과 소변의 지질과산화에 미치는 영향에 대하여 살펴보았으며, 지질과산화 정도를 측정하기 위해 HPLC를 통한 TBARS 정도를 측정하였다. 연구결과, 마우스에서 만성 에탄올 섭취는 뇌 조직 TBARS 생성에 영향을 주지 않는 것으로 나타났으나, 소변 TBARS는 Aldh2 (-/-) 마우스에서 에탄올을 투여함에 따라 유의한 증가를 보였다( $p<0.05)$. 본 연구 결과로부터 8 주간 에탄올을 경구 투 여한 마우스에서 $\mathrm{ALDH} 2$ 의 활성은 체내의 전반적인 활성산소 생성에는 중요하게 관여하는 것으로 보이지만 뇌조 직에서의 활성산소 생성에는 영향을 주지 않는 것으로 보이며, 이는 에탄올 노출과 이에 따른 활성산소가 다양한 만성 뇌질환을 유발한다는 기존의 가설에서 $\mathrm{ALDH} 2$ 의 활성이 중요하게 관여하지 않을 가능성을 시사한다. 